\title{
THE BOSTON MASSACRE: Design or Accident
}

\section{BY PETER BRODKIN}

Mr. Brodkin is a graduate student in history at Rutgers University.

The author would like to thank the staff of the Rutgers University Libraries for their help in the completion of this article.

\section{North End}

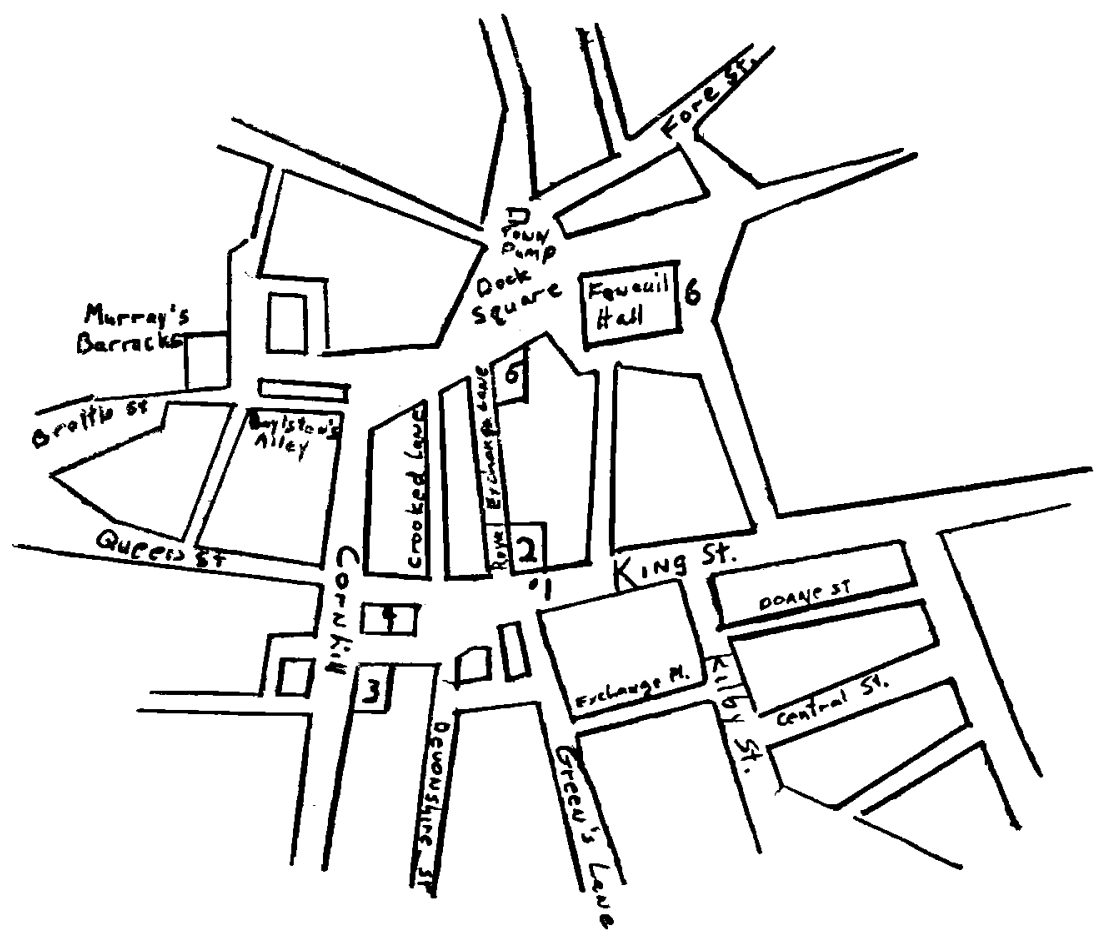

$$
\begin{aligned}
& \text { South End } \\
& \text { BOSTON I } 77^{\circ}
\end{aligned}
$$
I. Sentry Box
2. Customs House
3. Main Guard

* Annie Haven Thwing, The Crooked and Narrow Streets of the Town of Boston (Boston: Charles E. Lauriat Co., 1930), opposite page 78. 
It is a paradox of the violence in Boston during the years of 1765 to I 770 that although the rioters seemed uncontrolled and uncontrollable, they were in fact under an almost military discipline.... The Boston Mob's ardor there is little doubt, could be turned on or off to suit the policies of its directors. ${ }^{1}$

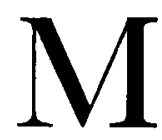

OST historians studying the actions of the mob in pre-Revolutionary America, and especially in Boston, would agree that many of these riots although seemingly spontaneous were actually organized with certain political ends in mind. John Shy, in his book Toward Lexington, indicates that mob action was one of a number of political weapons used by local leaders. The "first resistance to the troops in Boston occurred not on the waterfront but in the Court House." In almost all instances, according to Shy, when the town elders had certain grievances against the methods of the English they first tried to alleviate the problems through the legal means of petition and court action. Only when these channels failed did they call out the mob.

What then of the so-called Boston Massacre? Were the events of March 5, I770 simply the result of heightening tensions between the inhabitants of Boston and the occupying troops, and, therefore, just one of a number of spontaneous conflicts and street brawls that had occurred over the previous two years? Or, were the actions of the civilians prefabricated in an attempt to make the townspeople appear to be innocent victims of British oppression and thereby remove the troops from Boston? If the mob activity of March 5, I 770 was not planned in advance, could the quarrelsome and threatening assembly of citizens have been an organized, rather than spontaneous, reaction to severe attacks on the inhabitants by off-duty British regulars earlier that evening and over the previous few days?

Recent scholarship has suggested, but not explored, the possibility that the Massacre resulted from organized mob activities. According to Shy, "Circumstances suggest that there was as much purpose as spontaneity in the events leading up to the Massacre." Pauline Maier, in From Resistance to Revolution, goes a step further by suggesting that the Massacre was part of an effort to have the troops removed from

${ }^{1}$ Hiller B. Zobel, The Boston Massacre (New York: W. W. Norton and Company, Inc., 1970), pp. 28-29.

${ }^{2}$ John Shy, Toward Lexington (Princeton, N.J.: Princeton University Press, I965), p. 304 .

${ }^{3}$ Ibid., p. 319. 
Boston. "In later years, John Adams blamed the Massacre upon some unnamed townspeople who, he claimed, had tried for weeks to excite incidents between citizens and soldiers." Finally, there is an extremely provocative statement in a book by Wesley S. Griswold, called The Night the Revolution Began:

It became obvious to Samuel Adams and the Loyal nine at this time [following the Stamp Act riots in 1765 ] that excessive violence in the cause of colonial liberties might create martyrs rather than followers. From then on, except in the shameful instance of the Boston Massacre, in 1770, Mackintosh's Mob [the so-called Boston Mob, to be discussed later] became noticeably more disciplined, even marching in military formation at public celebrations. ${ }^{5}$

This statement would seem to indicate Griswold's belief that the inhabitants who gathered that night were members of the Boston Mob. If this were true it would seem to suggest at least a last minute organized reaction to the transgressions of off-duty soldiers. However, Griswold argues that this was the exception for an otherwise highly organized group, hinting that on just one occasion the well-controlled mob was out of control. This is of course a possibility and yet it seems difficult to understand how such a well-disciplined group could get out of control at all. Or, taken another way, if the existing tensions and the conflicts of the previous days had led to this massive uncontrolled reaction, why did similar circumstances during the years from I 768 to I 770 not result in similar disorders?

It is the intent of this study to explore the events of early March, I 770, especially with regard to the possibility that the Boston Massacre did not result from a spontaneous mob action, somewhat akin to the more modern urban riots of the I960's. The more he delves into the actions of the soldiers and the townspeople, the researcher cannot help but be impressed by the weight of circumstantial evidence which suggests that the antagonists were engaged in an organized conflict with specific objectives that they hoped to win.

There is well-documented evidence that by I 770 a tension-filled climate existed in Boston in regard to the relationship between British troops garrisoned in Boston and the townspeople, who did not like living

${ }^{4}$ Pauline Maier, From Resistance to Revolution (New York: Alfred A. Knopf, 1972), p. 125.

${ }^{5}$ Wesley S. Griswold, The Night the Revolution Began (Brattleboro, Vermont: The Stephen Green Press, 1972), p. 20. 
in an occupied city. ${ }^{6}$ Also, it must be added that the soldiers often moonlighted at other jobs when off duty and were, therefore, in direct competition for employment with many of the inhabitants. The civilians reacted both in language and in physical assault on the troops, who often retaliated. Shy says, "From the beginning, Bostonians had been probing for weak spots in the army. ... By Mid-summer [1769] it was becoming difficult to keep the soldiers from seeking redress in the streets." Incidents continued, some resulting in death, but more often the result was harassment or brawling. "Like an arpeggio of conflict, the tensions had been rising: Panton's death; the Riley fracas; Robinson's battle with Otis; the Ness-Molesworth affair; John Mein's mobbing; and now Serder's death and commemorative funeral."”

Throughout this period the Popular Party, whose membership included Samuel Adams, John Hancock, James Otis, Joseph Warren, and others, had been engaged in an intense campaign through legal channels, speeches, newspaper articles, and extra-legal activities, in an attempt to get the troops out of Boston.

What the radicals needed, as they clearly must have realized, was some kind of incident in which the town rather than the army would appear the injured party. ... Given the intense feelings on both sides, an intensity which [Sam] Adams had worked hard to increase, it would not be long before the soldiers would stumble into a fatal error. ${ }^{9}$

Zobel is not willing to say that it was more than a fatal error, which was inevitable, given the intense feelings existing at the time. Whether it was such a mistake or whether fate was given a helping hand, the event the Popular Party desired occurred on the evening of March 5, I770. Early that evening a group of off-duty soldiers left Murray's Barracks, went through Boulston's Alley and attacked everyone in their way on Cornhill with fists, bayonets, and cutlasses. The word spread like wild fire throughout the city and soon a group of club carrying inhabitants from the South End were in front of the barracks threatening the men

${ }^{6}$ An excellent and detailed account of the atmosphere of tension that existed in Boston in 1770 and of the activities of March 5 of that year is given in Hiller B. Zobel's The Boston Massacre. Therefore, this essay will only briefly summarize these events.

${ }^{7}$ Shy, Toward Lexington, pp. 313-314.

${ }^{8}$ These events are all explained in detail in Zobel's book. They are only used here to indicate the personal feeling created by transgressions against individuals which helped to heighten the already intense feelings in Boston.

Zobel, Boston Massacre, p. 180.

${ }^{9}$ Ibid., p. 18 I. 
inside and the officers, who were trying to keep order, on the front steps of the building.

While this crowd of twenty or thirty confronted the garrisoned troops a young barber's apprentice named Ed Garrick was insulting a British officer in front of the Customs House in King Street. The officer did not react but the sentinel stationed nearby did and struck Garrick on the side of the head with the butt of his gun. Garrick began to cry and other youths, attracted by this disturbance, began to hurl insults and snowballs at the sentry. He reacted by jabbing at the small crowd gathered around him with his bayonet. Garrick also seems to have wandered in front of Murray's Barracks, crying that he had been killed, which further enraged the group of civilians there. ${ }^{10}$

The townspeople who had gathered at the barracks began to disperse as it became apparent that they would not be able to retaliate further against the soldiers for their earlier assaults on Cornhill. Some went into King Street attracted by the small group near the sentinel's box. Others went home. Still others went to Dock Square where inhabitants from the North End began to gather. Coming down in groups after hearing of the earlier fighting in Cornhill, each group tried to rush up Boylston's Alley to the barracks but not being able to all fit through the narrow passageway or get at the soldiers in the barracks they returned to Dock Square.

After several forays through the alley those gathered at Dock Square decided that more people were needed and so they rang the bells of two nearby churches and many began to cry out, "Fire!" A larger group began to gather in the square, since the town pump, the source of water for fire prevention, was there. Those who remained after they realized that there was no fire, and who were not armed, broke into the market and dismantled some of the stalls to get clubs.

The crowd milled around Dock Square for a while and losing some of its anger many decided to return home. At that point a man described

${ }^{10}$ L. Kinvin Wroth and Hiller B. Zobel, ed., The Boston Massacre Trials, Vol. III of Legal Papers of John Adams (Cambridge, Mass.: The Belknap Press of Harvard University Press, 1965), pp. 183-185, note 93, also see p. 50, note 1 3 .

11 "Boston had no fire department; in the event of a fire, the largely wooden-built town depended for survival on organized volunteers. . . . When a church bell rang the alarm, Bostonians hurried en masse to the site ... in the night, an off-hour church bell meant only one thing. Thus when sometime after 9 pm [bells] began to peal, the town reacted instinctively. . . . All rushed toward the sound of the bells."

Zobel, Boston Massacre, p. 191. 
by witnesses as wearing a red cloak and white wig entered the square and spoke to the gathering for a few minutes. He was apparently recognized by many in the crowd and he quickly convinced some two or three hundred that they should try to confront the soldiers on duty at the Main Guard, on the corner of Cornhill and King Street. These people rushed through Cornhill and Royal Exchange Lane to King Street where they were attracted by the small group still gathered around the sentry.

Lieutenant Preston, in charge of the Main Guard, feared that the crowd would kill the sentinel. He took seven men and marched to the sentry's box, using their bayonets as prods to move through the crowd. Preston was delayed by one of the inhabitants who begged the officer not to have his troops fire. The seven regulars, arriving at their destination, began to load their weapons while waiting for their officer. Preston, upon arriving, ordered the sentry to fall in and then tried to march back to the Main Guard. This proved to be impossible since the crowd, growing more hostle and surrounding the troops, refused to allow them passage. The regulars then formed a semicircle facing the body of the gathering, which continued throughout this entire incident to hurl abuses and snowballs at the soldiers. Not more than fifteen minutes after Preston and his men had left the Main Guard, some of the soldiers fired on the crowd (apparently without orders but rather out of panic and in retaliation for the crowd's abuses) instantly killing three and fatally wounding two others. The townspeople quickly fled and the soldiers were able to return to the Main Guard.

The sounds of the guns discharging and of the crowd panicking brought still more of Boston's inhabitants into King Street. After the soldiers returned to the Main Guard the crowd in the street swelled to perhaps one thousand. The entire 29 th Regiment was called out from the barracks and was ordered to form up in "street firing" position for riot control. A few of the people in King Street ran to the North End and returned with the Lieutenant-Governor, Thomas Hutchinson, who addressed the crowd from the balcony of the Town House. Hutchinson asked the people to disperse promising that the entire matter would be investigated and justice would be done. However, some of the local leaders, who were present, told the Governor that the inhabitants would only disband after the troops had been sent back to their quarters. Hutchinson then turned the decision over to the commanding officer 
of the 29th, who ordered his men to retire. Following that order the crowd also began to break up. ${ }^{12}$

Peter Oliver and Lieutenant-Governor Hutchinson, both Tory residents of Boston in 1770 , later claimed that the Massacre was a conspiracy. Or, to be more precise, it was one of many events planned and directed by a revolutionary faction in Boston. These two observers saw the mob action of March 5 as being related to and similar to earlier activities like the Liberty Riots and the Stamp Act Riots.

According to common custom, when a riot was to be brought on, the factioneers would employ boys and negroes to assemble and make bonfires in the street; and when all were ready the mob whistle . . . with sometimes the mob horn in unison would echo through the streets. . . . Those boys and negroes assembled before the Customs House and abused ye sentinel [on the night of the Massacre].$^{13}$

Hutchinson, who knew little of the evening's events until he was summoned to the Town House, felt instant and renewed pressure to have the troops removed from Boston. His description of meetings the following day with leaders from Boston and neighboring towns hinted at further threats from these people:

The select men of Boston ... make their representations, that from the contentions arising from the troops quartered in Boston, and above all, from the tragedy of last night; the minds of the inhabitants were exceedingly disturbed; that they would presently be assembled in a town meeting, and that, unless the troops should be removed the most terrible consequences were to be expected. ${ }^{14}$

Despite being a vehement political adversary of Oliver and Hutchinson, Sam Adams also pictured the Massacre in conspiratorial terms. However, he blamed the riot not on an organized mob but on the soldiers:

... or it [the ringing of church bells] might be to alarm the town, from an apprehension of some of the inhabitants, that the Soldiers were putting their former threats into execution, and that there would be a general Massacre ....15

12 Ibid., pp. I 80-205.

${ }^{13}$ Douglass Adair and John A. Schutz, ed., Peter Oliver's Origin and Progress of the American Revolution (Stanford, Cal.: Stanford University Press, r961), p. 89.

${ }_{14}$ Thomas Hutchinson, The History of the Colony and Province of Massachusetts' Bay, ed. Lawrence Shaw Mayo (Cambridge, Mass.: Harvard University Press, 1936), vol. III, p. 197.

${ }^{15}$ Harry Alonzo Cushing, ed., The Writings of Samuel Adams (New York: G. P. Putnam's Sons, I906), vol. II, p. 94. 
There are indications from other sources that the soldiers' foray into Cornhill was a pre-planned attack on civilians probably as a redress for injuries inflicted by the civilians on the soldiers in many of the earlier street fights and confrontations:

It appeared by the oaths of credible witnesses that Soldiers had been to the houses of some of their friends the Sunday Evening before ... and [told them] ... to keep out of the way the next two nights following; that there would be more blood shed then. ${ }^{16}$

Considering the tension between the town's residents and the English soldiers, discussed earlier, such a planned attack on civilians should not be particularly surprising. It is more interesting to speculate on who planned the action rather than why. The source material gives little indication that anyone except the regulars themselves were involved. Yet, there is the curious fact that the soldiers tried for murder as the result of the Massacre were defended by John Adams and Josiah Quincy, both strong opponents to the quartering of troops in Boston. Contrary to popular belief, Adams and Quincy were not alone among Boston's antiBritish partisans in feeling that Preston and his subordinates deserved a fair trial and counsel despite the results of their action on King Street. ${ }^{17}$ In writing to his father Quincy said:

I refused all engagement [as Lawyer for Preston] until advised and urged to undertake it by an Adams, a Hancock, a Molineux, a Cushing, a Henshaw, a Pemberton, a Warren, a Cooper, and a Phillips. ${ }^{18}$

The reader will quickly see in this list most of the Popular Party leaders as well as names associated with the Loyal Nine and the Sons of Liberty. These men were not all lawyers and it would be difficult to argue that they all believed Preston and his men deserved a good defense from a strictly legal point of view. It should also be mentioned that the same people who pressured Quincy into the role as defense counsel were

${ }^{16}$ William Palfrey to John Wilkes, March I 3, I 770, Proceedings of the Massachusetts Historical Society (Boston: John Wilson and Son, I862), vol. VI, p. 481 .

"The North Briton, May I 2, 1770," Providence Gazette, July 7 to I4, 1770.

17 John Adams indicated that he defended the soldiers because, "I had no hesitation in answering that Council ought to be the very last thing that an accused Person should want in a free Country. That the Bar ought in my opinion to be independent and impartial at ali Times And in every Circumstance. And that Persons whose Lives were at Stake ought to have the Council they preferred."

L. H. Butterfield, ed, Diary and Autobiography of John Adams (Cambridge, Mass.: The Belknap Press of Harvard University Press, I97 I), vol. I, p. 293.

${ }^{18}$ Josiah Quincy, Memoir of the Life of Josiah Quincy, Junior, ed. Eliza Susan Quincy (Boston: Little, Brown and Company, 1875). Josiah Quincy, Jr. to Josiah Quincy March 26, I 770, p. 28. 
simultaneously pressuring the court to hold the trials quickly, while the memory of the Massacre was still fresh in the inhabitants' minds. ${ }^{19}$

Adams's and Quincy's action seems even more difficult to explain in light of the strong propaganda campaign waged by the Popular Party through its organ, the Boston Gazette. The issue of the Gazette which came out just after the Massacre was devoted almost entirely to a discussion of the event. No ink was spared in picturing the atrocious nature of the troops' actions that night and in earlier events. ${ }^{20}$ On succeeding anniversaries of the Boston Massacre large rallies were held at which speakers would remind the citizenry of the March 5th killing. One such speaker was the same Joseph Warren who encouraged Josiah Quincy to defend Preston. ${ }^{21}$

It would be a great flight of fancy to suggest that the Popular Party leadership or the Loyal Nine had conspired with the English soldiers and were, therefore, only defending their lackeys when they came to trial. It would seem more likely that they saw this trial as another propaganda vehicle, which could be used to discredit the English presence in Boston. Since the prosecution and defense could manipulate the testimony given in court, the best way to have the most damaging evidence presented, while putting on record little or nothing that would blame the townspeople, was to have members of the Popular Party take up the defense. It should be noted that the immediate effect of this propaganda campaign was to convince both the civil and military representatives of the Crown to call for the removal of British troops from Boston. ${ }^{22}$

Thus, if one looks at the Boston Massacre as a media or propaganda event that was effectively used in a drive by the radicals to have the English troops withdrawn from Boston, the reader must again question the spontaneity of the activities which took place on March 5, I770. As John Adams tells us:

Endeavors had been systematically pursued for many months, by certain busy characters, to excite quarrels, rencounters, and combat, single or compound, in the night, between inhabitants of the lower class and the soldiers.

${ }^{19}$ Wroth and Zobel, Legal Papers, vol. III, p. 3.

20 "Boston, March i 2," Boston Gazette, March i2, 1770.

${ }^{21}$ John Cary, Joseph Warren (Urbana, Ill.: University of Illinois Press, I961), p. 107.

For the text of Warren's Boston Massacre speech see: Merrill Jensen, ed, American Colonial Documents to ${ }_{177} 6$ (New York: Oxford University Press, 1955), pp. 753-759. 22 "Boston, March 12," Boston Gazette, March 12, I770. 
... I suspect that this was the explosion which had been intentionally wrought up by designing men, who knew what they were aiming at . . . ${ }^{23}$

There can be no doubt that at least part of the crowd that rushed into King Street from Dock Square were not assembled spontaneously but by the design of those already in Dock Square. David Mitchelson, one of several witnesses who watched the proceedings in Dock Square from the balcony of William Hunter's home, said in trial testimony that:

It was proposed by several of them to call out fire! Fire was called several times, and then the bells were set a ringing. This drew a great concourse of people, not knowing but it was a fire. The greatest part had sticks of various sorts. ... ${ }^{24}$

Although, Mitchelson insisted that these newcomers believed that they were going to a fire, further testimony and even Mitchelson's own observation seemed to indicate that many had a better understanding of what actually was going on. Mitchelson himself observed that a large number of those who were summoned by the alarm carried sticks and other witnesses noted that they had never seen people going to a fire armed with clubs before. Still other witnesses told of being informed by people in the streets that a fight was in progress rather than a blaze. A few examples of such testimony are:

John Cookson-A man said if the bells were ringing it was he apprehended an affray with the soldiers.

Dimon Molton-Between 9 and Io I heard in my house the cry of fire but soon understood that there was no fire but the soldiers were fighting with the inhabitants.

Newton Prince - Bell ring, ran out ... was told there was no fire but something better, there was going to be a fight. ${ }^{25}$

The evidence taken in two trials later in 1770 , which were attempts to place blame for the Massacre, seemed to indicate that, except for the twenty odd youths already taunting the sentry the crowd that gathered in King Street, did not arrive there spontaneously, rather they were instructed to go to King Street by the unidentified figure in Dock Square. Most of the townspeople were beginning to disperse when:

a gentleman came up with a red cloak, they gathered round him and he stood in the middle of them, and they were all very quiet; he spoke to them

${ }^{23}$ Charles Francis Adams, ed., The Works of John Adams (Boston: Charles C. Little and James Brown, 1850), pp. 229-230.

${ }^{24}$ Wroth and Zobel, Legal Papers, vol. III, P. I 73 , note 74 .

25 Ibid., pp. 58-59, 77, I 79 . 
a little while, and then he went off, and they took off their hats and gave three cheers for the Main-Guard; then went up Royal Exchange Lane as fast as they could. ... ${ }^{26}$

The assembly in Dock Square seemed to recognize this man and from the testimony he appears to have had great influence over them. When he arrived everyone gathered around him and listened attentively and then following only a two or three minute address, he seems to have convinced the crowd to confront the Main Guard. ${ }^{27}$ The identity of this figure remains a mystery because none of the witnesses claimed to know him. However, it seems intuitively possible that not only the gathering in Dock Square recognized him but some of those observing from Hunter's balcony may also have known his identity. His dress was that of a public officeholder, probably a minor official, who like most minor officials was likely to have gotten his position through an appointment by a caucus of the Popular party. If this man in a red cloak was indeed such an officeholder, William Hunter, who was also a minor official, and James Selkreg, who was a merchant, probably would have recognized him from their vantage point. At any rate their view was not hindered by the dark of night since much of the testimony indicated that there was a full moon. It can also be expected that the snow and ice on the ground made an open area like Dock Square quite bright. ${ }^{28}$

In his book on Joseph Warren, John Cary attempts to identify the red cloaked figure in a footnote. Unfortunately his attempt is not strongly documented:

The speaker was blamed by the conservatives for the violence of the night. The intimation was that he was a public officeholder, since the red coat and white wig were common with eighteenth century officials. Some evidence points to William Molineux as the speaker. A British officer blamed for the affair, and Warren used him when threats and violence were required. One witness testified to being in a house with Molineux when the firing occurred. Abigail Adams described Joyce Junior, whose name was often signed to threatening notes of the Sons of Liberty as wearing a red coat and white wig. ${ }^{29}$

There seems to be no evidence of the presence of Joyce Junior in King Street or Dock Square at any time during the evening of March 5. However, William Molineux was present. He was one of the vocal town

\footnotetext{
26 Ibid, p. I72, note 73 .

${ }^{27}$ I bid., p. I 73 , note 74 , p. 177 , note 81 .

28 Ibid., pp. 173 , 177.

${ }^{29}$ Cary, Joseph Warren, pp. 92-93, note 38.
} 
leaders who told Hutchinson that the crowd in front of the Town House would not disperse until the soldiers returned to their barracks. ${ }^{30}$

What then of those from the South End who confronted the soldiers at Murray's Barracks or those from the North End who first assembled in Dock Square? Were they an unorganized reaction to the attacks on civilians by off-duty regulars earlier that evening? Or, were they an organized party with specific goals in mind? The fact that they came from the North and South Ends is somewhat suggestive. For a number of decades two entities known as the North and South End Mobs had existed. Their main function had been a sort of brawl annually held on November 5. However, from the time of the Stamp Act Riots in I765 and into the American Revolution these gangs had been reorganized into a single unit known as the Boston Mob. This force was used as the extra-legal arm of the anti-British Loyal Nine and later of the Sons of Liberty. ${ }^{31}$ Extensive research by the Morgans for their book, The Stamp Act Crisis, indicates that the mob had been organized into a military-like unit under the command of South Ender Ebenezer Mackintosh, who was a minor city official appointed by a caucus of the Popular Party. ${ }^{32}$ Peter Oliver described the mob as follows:

The leaders of the faction [who were against the Stamp Act] had hired a shoemaker, named Mackintosh. . . . He was sensible and manly, and performed their dirty jobs for them with great eclat. He dressed genteelly; and in order to convince the public of that power with which he was invested, he paraded the town with a mob of 2000 men in two files. . . If a whisper was heard among his followers, the holding up of his finger hushed it ... he marched his men to the first rendezvous, and ordered them to retire peaceably to their several homes; and was punctually obeyed. ${ }^{33}$

Although research by George P. Anderson indicated that 1770 was in the middle of an inactive period for Mackintosh, mostly because of a

\footnotetext{
${ }^{30}$ Hutchinson, History of Massachusetts' Bay, p. 196.

${ }^{31}$ George P. Anderson, "A Note on Ebenezer Mackintosh," Colonial Society of Massachusetts Publication, XXVI (1927), 357-360.

Maier, From Resistance to Revolution, p. I 25.

Edmund S. Morgan and Helen M. Morgan, The Stamp Act Crisis (Chapel Hill, N.C.: The University of North Carolina Press, 1953), pp. I22-123.

Annie Haven Thwing, The Crooked and Narrow Streets of the Town of Boston (Boston: Charles E. Lauriat Co., 1930), pp. 78-79.

Zobel, The Boston Massacre, pp. 37-38.

32 Morgan, The Stamp Act Crisis, p. 121.

Zobel, The Boston Massacre, p. 27.

${ }^{33}$ Adair and Schutz, Peter Oliver's Origin and Progress, p. 54.
} 
marriage commitment to his wife, ${ }^{34}$ there is some indication that those assembled in Dock Square belonged to the Boston Mob. Witnesses at one of the resulting trials described the people coming from the South and North Ends as walking in an almost formation-like manner and saying things which suggested premeditation:

John Thompson-I went through Quaker-Lane into Green's Lane . . . I met about fifteen persons walking on different sides of the Street, and they had sticks in their hands... heard them say, we are rather too soon.

John Gillespie - I went from my own house in Queen Street ... to spend the evening with some company at Mr. Sylvester's at the South End, in my way I met not less than fifty people, with white sticks in their hands, in small parcels, and the company [at Sylvester's] all observed they met with numbers of people, and said they were apprehensive of the consequences.

William Davis-Monday evening ... I was going toward the North End in Fore-Street ... . [and met] about two hundred ... I saw several armed with clubs and large sticks, and some had guns, they came down regularly in two's and three's abreast [although Davis, who was a sergeant in the 14th Regiment, insisted that they were not soldiers] . . . some of them said they would go to the Southward, and join some of their friends there and attack the damned scoundrels and drive them out of town for they had no business here...

While in Dock Square the crowd's formation was described by David Mitchelson as being "assembled in various little knots, with various leaders, I suppose every party had a leader . .."35

This of course is not proof positive that the crowd was actually the Boston Mob. However, the description of military-like processions toward the central area of the town and the indications of premeditation, especially if we can believe Sergeant Davis' account, seem to indicate that the possibility of organized mob activity cannot be ruled out. None of the sources examined would appear to suggest that riot action was planned well in advance, but that it was probably a reaction to the events of the early evening coupled with the long-standing tensions between the soldiers and the townspeople. On the other hand the evidence clearly shows that the people did not just arrive in the business center in small angry groups but in large groups (twenties or fifties) from ends of town where members of the Boston Mob lived. It would

\footnotetext{
${ }^{34}$ George P. Anderson, "Ebenezer Mackintosh; Stamp Act Rioter and Patriot," Colonial Society of Massachusetts Publication, XXVI (1927), 46.

${ }^{35}$ Wroth and Zobel, Legal Papers, p. I73, note 74, p. 178, note 84, p. 189, note 98, p. 193.
} 
seem possible, therefore, that this reaction to earlier events was an organized action directed by men who had used confrontations like this for political purposes before, who were dedicated, for a host of reasons, to removing the troops from Boston, and who hoped that their ends could be reached by political pressure resulting from civil disorder.

This study has endeavored to examine the Boston Massacre from two perspectives. First it examines the events of the evening of March 5, I770. Second it explores the broader viewpoint of the Boston radicals, who were attempting to remove the English military presence from Massachusetts Bay. In the former it was discovered that the rioters lived in the sections of town which were closely associated with the membership of the Boston Mob. Indeed many seem to have marched to Dock Square in groups, as eyewitnesses reported, which resembled quasimilitary formations. Trial testimony indicated that many who arrived in the square knew that the ringing church bells meant something other than a fire alarm. In fact some said they knew those bells indicated a confrontation with the British troops. Some of those, who arrived in Dock Square, were armed with clubs, others upon their arrival armed themselves by dismantling the market stalls. Finally, there is the unidentified figure who came to the square, immediately received the attention of those present and quickly convinced them to move toward a confrontation with the soldiers at the Main Guard.

With these aspects in mind it would be difficult to argue that the rioters were not organized. If they were unorganized, why did many arrive in Dock Square in quasi-military fashion? How did they know that an alarm, which always meant fire, on that night meant confrontation? If they thought they were going to fight a fire, why did they arm themselves with sticks, rocks, and clubs? Finally, if they were a leaderless rabble, how was the unidentified person able to quickly gain their attention and direct their energies?

On the other hand, if the mob was organized and their activities directed, who was responsible for this leadership? The Boston Mob, of course, was organized by Ebenezer Mackintosh under the auspices of the Loyal Nine and the Popular Party. Still it is not immediately apparent that the rioters were indeed members of the Boston Mob, especially since Mackintosh may not have been involved. The second perspective of examination in this study discusses the Boston Massacre as a propaganda event. Those who were trying to remove the British 
troops from Boston saw the need for an event that would make those soldiers appear to be belligerent toward the civilians and the military presence a threat to civil tranquility. Following the Massacre those same people mounted a quick and effective anti-quartering campaign. Of course those who were the most outspoken against the troops in Boston were members of the Popular Party, the Loyal Nine, and the Sons of Liberty. These groups controlled a well-organized section of the citizenry, who could be called out if necessary to confront the English. When the soldiers in Murray's Barracks decided to vent their anger in Cornhill, the mob's leadership saw the long awaited possibility of a riot, precipitated by the actions of the British troops quartered in Boston. The mob was called out and pointed toward such a confrontation. The events of that evening probably turned out to be more dramatic than was expected. When Preston's little command fired into the crowd they created the first martyrs for the anti-English cause. 